\title{
Melting ice triggers Himalayan flood warning
}

Natasha McDowell, London

Melting glaciers high in the Himalayan mountains are creating unstable lakes that threaten to burst their banks, endangering the lives of tens of thousands of people, according to a United Nations report.

Although not new, the frequency of such floods has risen in the past 30 years. The increase is blamed on global warming by the report, which was written by researchers at the United Nations Environment Programme (UNEP) and the International Centre for Integrated Mountain Development, based in Kathmandu, Nepal.

Ground surveys and satellite images have identified 44 lakes in Nepal and Bhutan as being in danger of bursting the natural dams constraining them within 5-10 years. Data from 49 monitoring stations across Nepal indicate that air temperatures in the area are on average $1{ }^{\circ} \mathrm{C}$ higher than they were in the 1970s.

In Bhutan, some melting glaciers are retreating by 30-40 metres a year, according to the report, and in Nepal's Dolakha District the glacier feeding the Tsho Rolpa lake has retreated by up to 100 metres a year. The lake has grown sixfold since the 1950s, putting 10,000 people and a hydroelectric power station at risk.

Glacial lakes form behind moraines dams of rocks, debris and ice that are

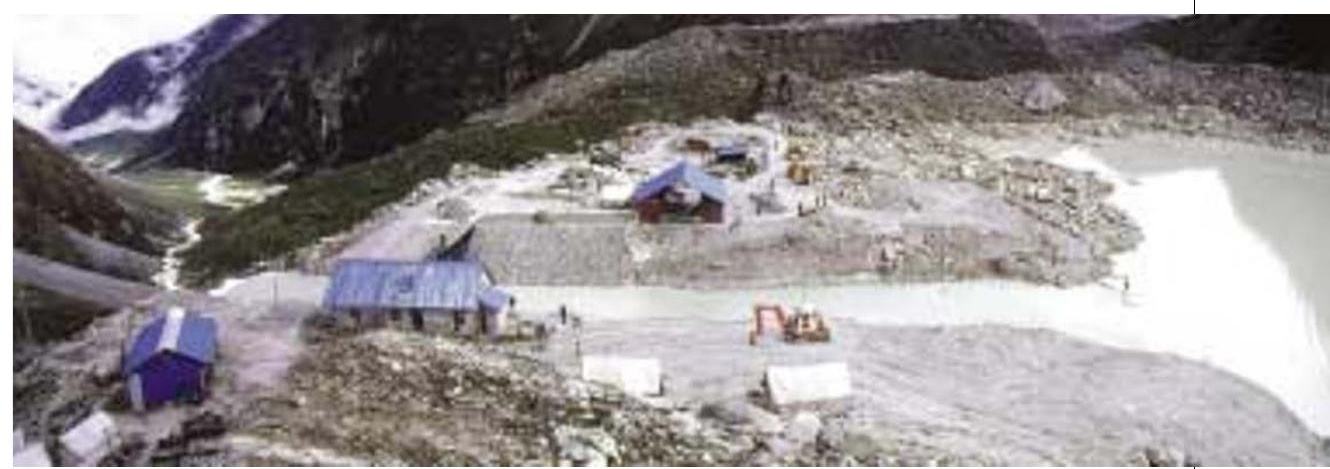

Water works: operations under way at Tsho Rolpa lake, which has grown sixfold since the 1950s.

left behind as the glacier retreats. These can quickly collapse; a small leakage as the ice melts is easily enlarged, and escaping water effectively eats the moraine from the inside out.

"Water was lapping the top of Tsho Rolpa's moraine and we didn't know how much time we had before it would burst," says John Reynolds, a geophysical engineer at Reynolds Geo-Sciences, a consultancy based in Wales, who is advising the Nepalese government on Tsho Rolpa.

Initial piping to siphon off the water proved insufficient to deal with the rising levels at Tsho Rolpa, Reynolds says. So two years ago, an emergency drainage channel was cut through the moraine to lower the water level by 3.5 metres. This was a tough job, he points out - the lake lies at an altitude of 4,500 metres and is 60 kilometres from the nearest road. Materials and equipment had to be brought in by porters or helicopters.

The work, which was paid for by the Dutch government, reduced the lake's volume by one-sixth and has allowed part of the moraine to dry out, thereby stabilizing it. But now two large iceblocks in the moraine are melting and the water level needs to be lowered further.

Tsho Rolpa is just one of many lakes facing the same problem. Klaus Toepfer, UNEP's executive director, described the problem as "another compelling reason to act to reduce emissions of carbon dioxide and other greenhouse gases".

\section{Twice-rescued Bronze Age disc goes on public view}

Marion Kerstholt, Munich

A bronze disc depicting the Sun, Moon and stars, which went on public exhibition in Germany this month, has sparked a debate about the astronomical expertise of

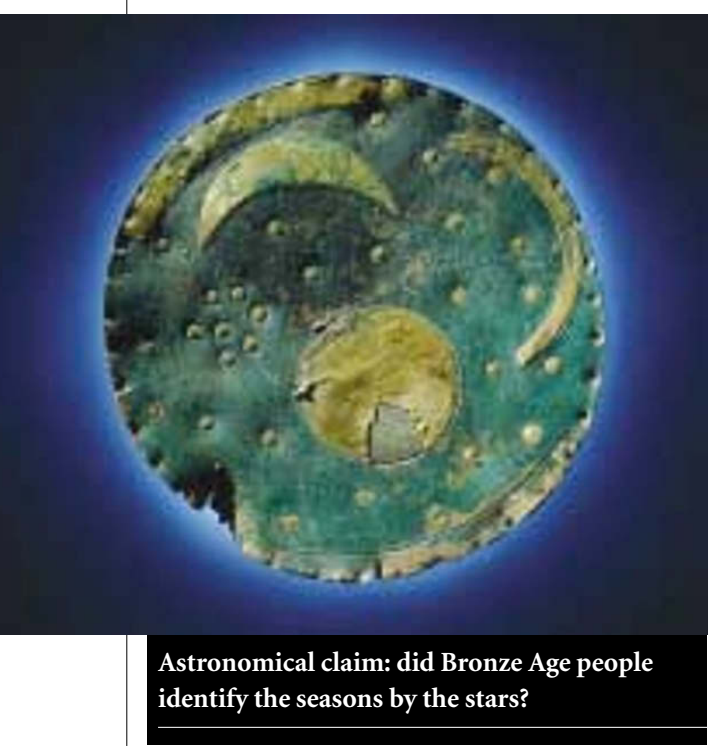

Bronze Age Europeans. Intrigued archaeologists and astronomers can thank the police, who recovered the artefact after it was stolen from a site at Sangerhausen in the state of Saxony Anhalt, 100 kilometres west of Leipzig.

The gold-decorated disc is on show at the State Museum of Prehistory in Halle. Some 3,600 years old, it may be the first 'scientific' representation of the sky of central Europe, claims Wolfhard Schlosser, an astronomer at Ruhr University in Bochum. He believes that the disc represents the constellation Pleiades.

At the time the disc was made, Pleiades was not visible from central Europe in spring. So the constellation's disappearance might have been used to herald the season's arrival. Alix Henseler, an expert on the Bronze Age at the Museum of Prehistory in Berlin, says the disc suggests that "people living in middle Europe in the Bronze Age were able to draw seasonal conclusions from observations of stars".

But other astronomers are not convinced. "The bronze disc is clearly a remarkable object, but as an astronomical piece it is very primitive," says Owen Gingerich, an expert in the history of astronomy at the HarvardSmithsonian Center for Astrophysics in Cambridge, Massachusetts. He disputes whether the pattern of stars represents a specific constellation.

Experts can count themselves lucky that they are able to debate the object's significance at all. In 1998, two amateur archaeologists excavated the disc and sold it to a dealer for 15,000 euros (US\$13,300) although under German law all such finds belong to the federal republic. The dealer unsuccessfully tried to sell it to the Berlin museum.

A go-between, who later claimed that she had wanted the disc to stay in Germany, then sold it to a Düsseldorf schoolteacher. Believing that Harald Meller, chief of Saxony Anhalt's department of archaeology, might want to buy the disc for the state, the gobetween invited him to meet the teacher in February this year. But Meller was already working closely with German police, and both the teacher and the go-between were arrested. They have yet to be charged. 